\title{
Deconstructing Indian cotton: weather, yields, and suicides
}

\author{
Andrew Paul Gutierrez ${ }^{1,2}$, Luigi Ponti ${ }^{2,3}$, Hans R Herren ${ }^{4}$, Johann Baumgärtner ${ }^{2,4}$ and Peter E Kenmore ${ }^{2}$
}

\begin{abstract}
Background: Cotton with coevolving pests has been grown in India more than 5000 years. Hybrid cotton was introduced in the 1970s with increases in fertilizer and in insecticide use against pink bollworm that caused outbreaks of bollworm. Hybrid Bt cotton, introduced in 2002 to control bollworm and other lepidopteran pests, is grown on more than $90 \%$ of the cotton area. Despite initial declines, year 2013 insecticide use is at 2000 levels, yields plateaued nationally, and farmer suicides increased in some areas. Biological modeling of the pre-1970s cotton/pink bollworm system was used to examine the need for Bt cotton, conditions for its economic viability, and linkage to farmer suicides.

Results: Yields in rainfed cotton depend on timing, distribution, and quantity of monsoon rains. Pink bollworm causes damage in irrigated cotton, but not in rainfed cotton unless infested from irrigated fields. Use of Bt cotton seed and insecticide in rainfed cotton is questionable.

Conclusions: Bt cotton may be economic in irrigated cotton, whereas costs of Bt seed and insecticide increase the risk of farmer bankruptcy in low-yield rainfed cotton. Inability to use saved seed and inadequate agronomic information trap cotton farmers on biotechnology and insecticide treadmills. Annual suicide rates in rainfed areas are inversely related to farm size and yield, and directly related to increases in Bt cotton adoption (i.e., costs). High-density short-season cottons could increase yields and reduce input costs in irrigated and rainfed cotton. Policy makers need holistic analysis before new technologies are implemented in agricultural development.
\end{abstract}

Keywords: Ecological disruption; Bt cotton; Weather; Yields; Suicides; Bio-economics; Physiologically based demographic models; GIS; Climate change

\section{Background}

Native diploid "Desi" cottons (varieties of Gossypium arboreum L. and G. herbaceum L) have been grown in India for more than 5000 years without synthetic inputs [1] (i.e., functionally whether or not certified organically). Cotton was also domesticated in Africa and the Americas, and for all but the past 180 years, India was the center of world cotton innovation (see Additional file 1 for a review of the agronomic and political history). Cotton was the target of strong selection and adaptation by Indian farmers, but several agronomic changes altered the ecology and economics of cotton production in India as cotton became the raw material for the world's largest

\footnotetext{
* Correspondence: casas.global@berkeley.edu

${ }^{1}$ College of Natural Resources, University of California, 94720-3114 Berkeley,

CA, USA

${ }^{2}$ Center for the Analysis of Sustainable Agricultural Systems (CASAS NGO),

Kensington, CA, USA

Full list of author information is available at the end of the article
}

manufacturing industry-cotton textiles through the first half of the Industrial Revolution [1]. Starting in 1790, new world cottons (chiefly G. hirsutum L. and later G. barbadense L.) were introduced [2] with F1 hybrid cotton (normally G. hirsutum) introduced in the 1970s [3] ushering in high use of insecticide and fertilizer $[4,5]$. Planting of transgenic (i.e., genetically modified) F1 hybrid Bt cottons expressing endotoxins of the soil bacterium Bacillus thuringiensis for control of lepidopteran pests began in 2002 [6], and by 2012, more than 1128 Bt hybrid varieties of variable quality were planted on $92 \%$ of the cotton area $[2,7]$. Seed from F1 hybrid plants are fertile but are not usually saved for planting by farmers because they produce variable phenotypes, and hence seed must be purchased annually.

\section{Cotton pests}

Worldwide, cotton is attacked by ecologically similar complexes of insect herbivores (see Additional file 1). In 
India, before the widespread use of insecticide, the key pest of cotton was the cosmopolitan stenophagous semitropical pink bollworm (Pectinophora gossypiella Saunders; hereafter pink bollworm (PBW))) and also generalists such as jassids (Amrasca biguttula Ishida), spotted bollworm (Earias vitella Fabricius), and defoliators such as Spodoptera litura (Fabricius) [8, 9]. PBW is thought to be of South Asian, Papua New Guinea, and North Australian origins [10] and historically has been a pest in long-season cotton grown more than 180 days [2]. Natural control of $\mathrm{PBW}$ is weak, and it can cause high late-season damage if not controlled.

Before the introduction of Bt cotton, insecticide was used to control pink bollworm, and as has occurred worldwide wherever PBW infests cotton, insecticide use caused ecological disruption due to the destruction of generalist natural enemies resulting in the resurgence of PBW, outbreaks of formerly secondary pests, insecticide resistance, and adverse ecological and human health effects [11-13]. In India, pesticide use in all crops peaked in the 1990 s at 75,000 metric tons of active ingredient. Insecticides were $80 \%$ of this total, and 40 to $50 \%$ was applied to cotton [9]. The use of pyrethroids and organo-phosphate insecticides induced outbreaks of the polyphagous bollworm (Helicoverpa armigera (Hübner)), whitefly (Bemisia tabaci (Gennadius)), and other pests [9] that proved more damaging and difficult to control than PBW $[8,9]$. Prior to the 1970s, when high insecticide use began, bollworm and whitefly were minor pests in Indian cotton, but by 2002, when Bt cotton was introduced, $75 \%$ of insecticide use in cotton was for bollworm control [14]. Insecticide resistance was found in the defoliator S. litura in the late 1980s and in several other pests including pink bollworm and bollworm in the 1990s [14]. The inescapable conclusion is that Bt cotton was introduced to India to solve a bollworm problem created by insecticide use $[9,14]$.

The introduction of Bt cotton generated considerable controversy $[15,16]$ as some linked high suicide rates among cotton farmers to Bt cotton adoption [17] while others dismissed the links $[18,19]$. Unrealistic claims of $70-80 \%$ increases in yield [20], and $17-20 \%$ increases nationally $[18,19,21]$ entered the literature with some questioning these conclusions [22]. The above biology and controversy are imbedded in the historical economic, political, social (religion, caste, level), and ecological milieu of rural India and are background for our analysis of cotton production in India [23].

Because insecticides induce outbreaks of bollworm and other secondary pests (see Additional file 1), we first assess the historical baseline relationship of non-Bt cotton and PBW to understand the ecology of cotton production in India before heavy pesticide use and bollworm outbreaks began. In the process, we explain why despite conjectured high pest pressure, organic cotton continues to be grown in India. In order, the distribution of cotton in India is reviewed, and the ecology of irrigated and rainfed non-Bt cotton and PBW is examined in detail using the Yavatmal district, Maharashtra (MH) state, in central India as an example. The analysis is then extended to rainfed cotton across the agro-ecological zones of India with special focus on the central and southern states of Andhra Pradesh (AP), Gujarat (GJ), Karnataka (KA), and Maharashtra $(\mathrm{MH})$ where rainfed cotton predominates and where most of the farmer suicides have occurred. The study assesses the effects of weather on cotton yield and on risk. Three interrelated issues are addressed: was Bt cotton in irrigated and rainfed areas needed to solve pest problems, does it give economic benefits, and is its adoption linked to increases in farmer suicides.

\section{Results}

\section{Distribution of cotton}

The distribution of cotton across India is summarized in Fig. 1a, average yields in Fig. 1b, and the areas of irrigated and rainfed cotton in Fig. 1c, d, respectively [24, 25]. Most cotton in India is rainfed (Fig. 1d, e) with higher rates of irrigated cotton planted in the states of Punjab (PJ), Haryana (HR), and Rajasthan (RJ) (see map Fig. 1c, e). Cotton in AP, GJ, KA, and MH is mostly rainfed, but some irrigated cotton is also grown (see Fig. 1c vs. 1d).

\section{Irrigated non-Bt cotton at Yavatmal}

The biology of irrigated non-Bt cotton and PBW dynamics are simulated for Yavatmal, MH (symbol • in Fig. 1e; Fig. 2) on a daily basis using 2005-2010 weather to illustrate the level of detail computed for all areas of India (see "Methods"; Additional file 1). Soil fertility and water are assumed not limiting with prospective yields being a function of temperature and solar radiation. We note however that most of the irrigation water in southcentral India is from tube wells that access hard rock aquifers, the recharge of which is likely slower than the use rate and hence may not be sustainable [26]. Irrigated cotton has two or more fruiting cycles (Fig. 2a) and can produce high yields (Fig. $2 \mathrm{~b}$ ). For convenience, the simulations were terminated on 31 December each year.

Dormancy in larvae evolved to enable PBW to bridge yearly crop cycles [27-29] (Fig. 2c) resulting in the population dynamics illustrated in Fig. 2d. The rate of dormancy induction is a function of temperature and day length (Fig. 2e) with the stippled area indicating the parameter space for PBW at Yavatmal [28]. Temperatures drop with the onset of the monsoon season (see Fig. 3a, b) that along with decreasing day length increases dormancy rates in PBW (see Additional file 1). PBW adults emerge from winter dormancy during spring through midsummer; this adaptation is well timed to exploit fruiting in irrigated cotton (Fig. 2c). Infestation of fruit begins in late 


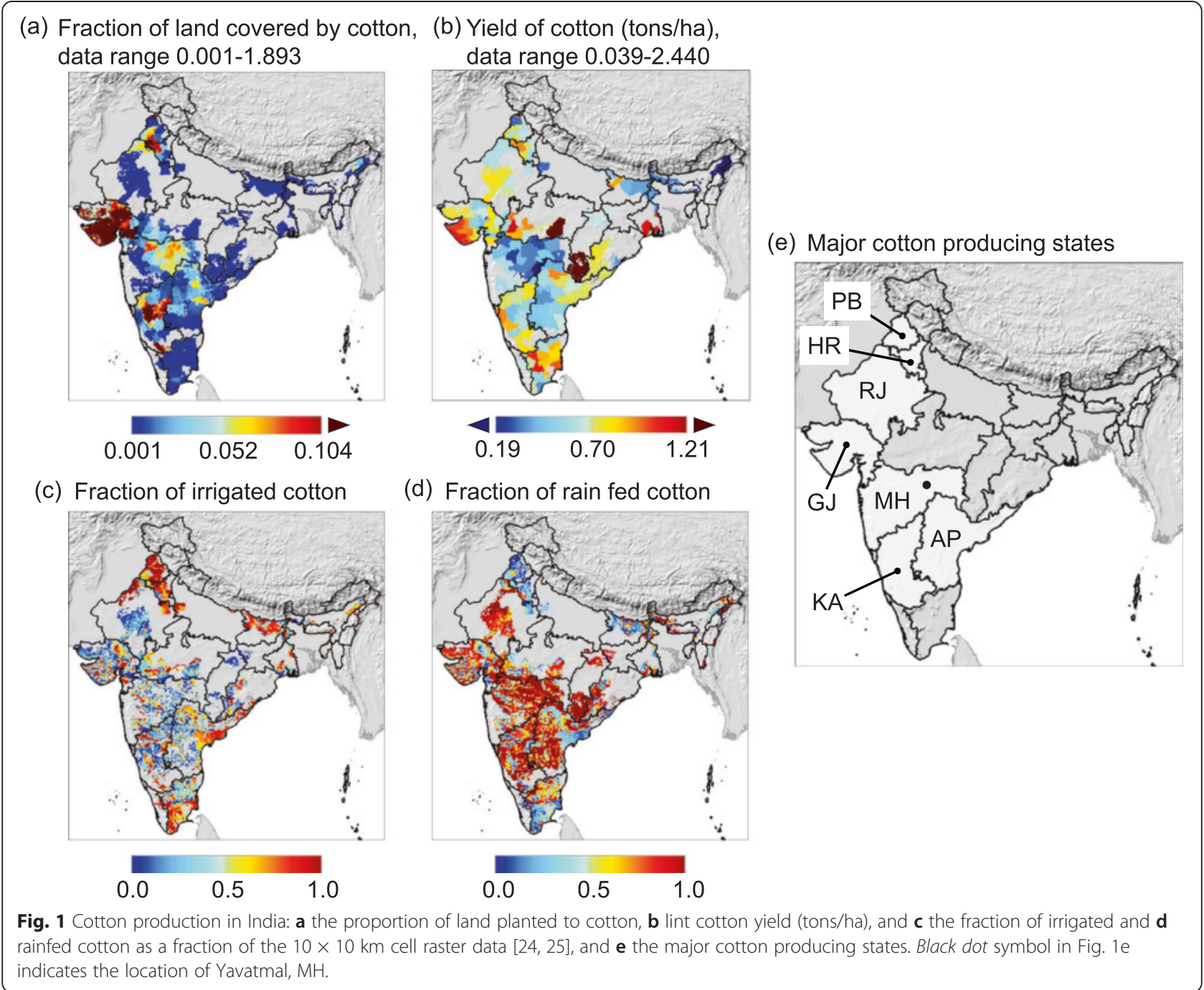

May-June and results in heavy late-season damage (Fig. 2d). Several larvae may develop per mature fruit with the proportion reduction in lint yield being $0 \leq \phi=0.061$ mean larvae/boll $<1$ [30]. As occurs in other areas of the world, insecticide use to control PBW in India induces outbreaks of bollworms, defoliators, whiteflies, and other pests [29, 31-34].

\section{Rainfed non-Bt cotton at Yavatmal, $\mathrm{MH}$}

At Yavatmal, the time and intensity of the monsoon rains (Fig. 3b, c) determine the time and success of seed germination, season length, and yield (Fig. 3d). Soil fertility is assumed not limiting, whereas available soil moisture is shown in Fig. 3c with the horizontal dashed line indicating the wilting point. For example, early monsoon rains during 2001 germinated the seed but were insufficient to sustain full growth with water stress during July slowing plant growth (Fig. 3d). Late rains in
August 2001 were not timely enough for the crop to recoup yield potential. Water stress also occurred during 2002 and 2003 and influenced yields. Emergence of PBW adults from dormancy during spring and summer is poorly timed with cotton fruiting, and sizeable PBW populations failed to develop (not shown).

Prospective yields during 1979 to 2010 are summarized in Fig. 4a with degree days (dd) above $12{ }^{\circ} \mathrm{C}$ and total rainfall indicated. The variable $\mathrm{dd}$ is the sum of daily degrees of temperature above the developmental threshold for cotton of $12{ }^{\circ} \mathrm{C}$ (i.e., physiological time) during the growing period. Predicted yields and lack of sizeable PBW populations (not shown) accord qualitatively with long-run field studies on rainfed cotton at Nagpur, $\mathrm{MH}$, roughly $100 \mathrm{~km}$ to the NW of Yavatmal [5, 35]. Multiple regression of yield on rainfall and dd indicates that only rainfall was a significant predictor of yield at Yavatmal that 


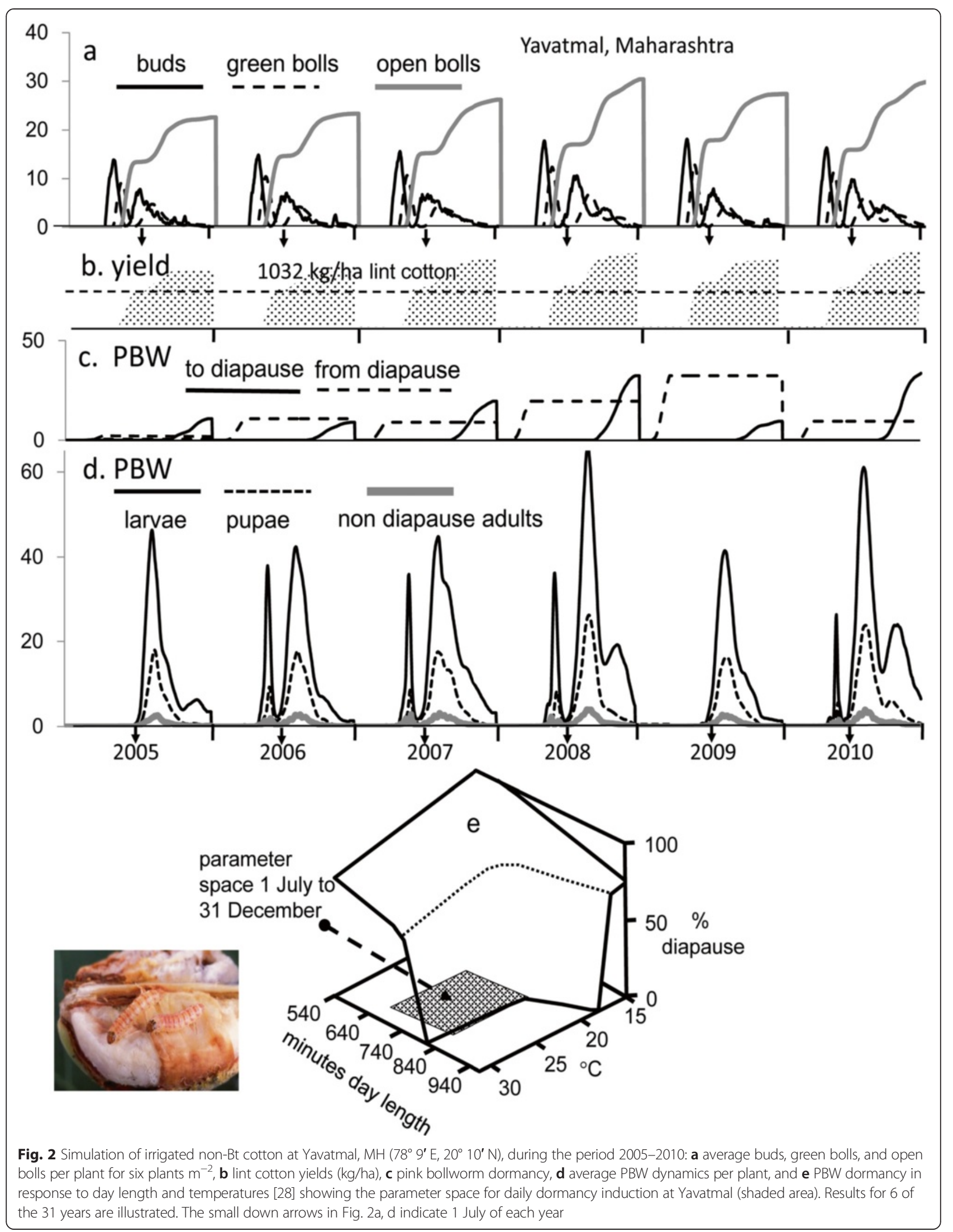




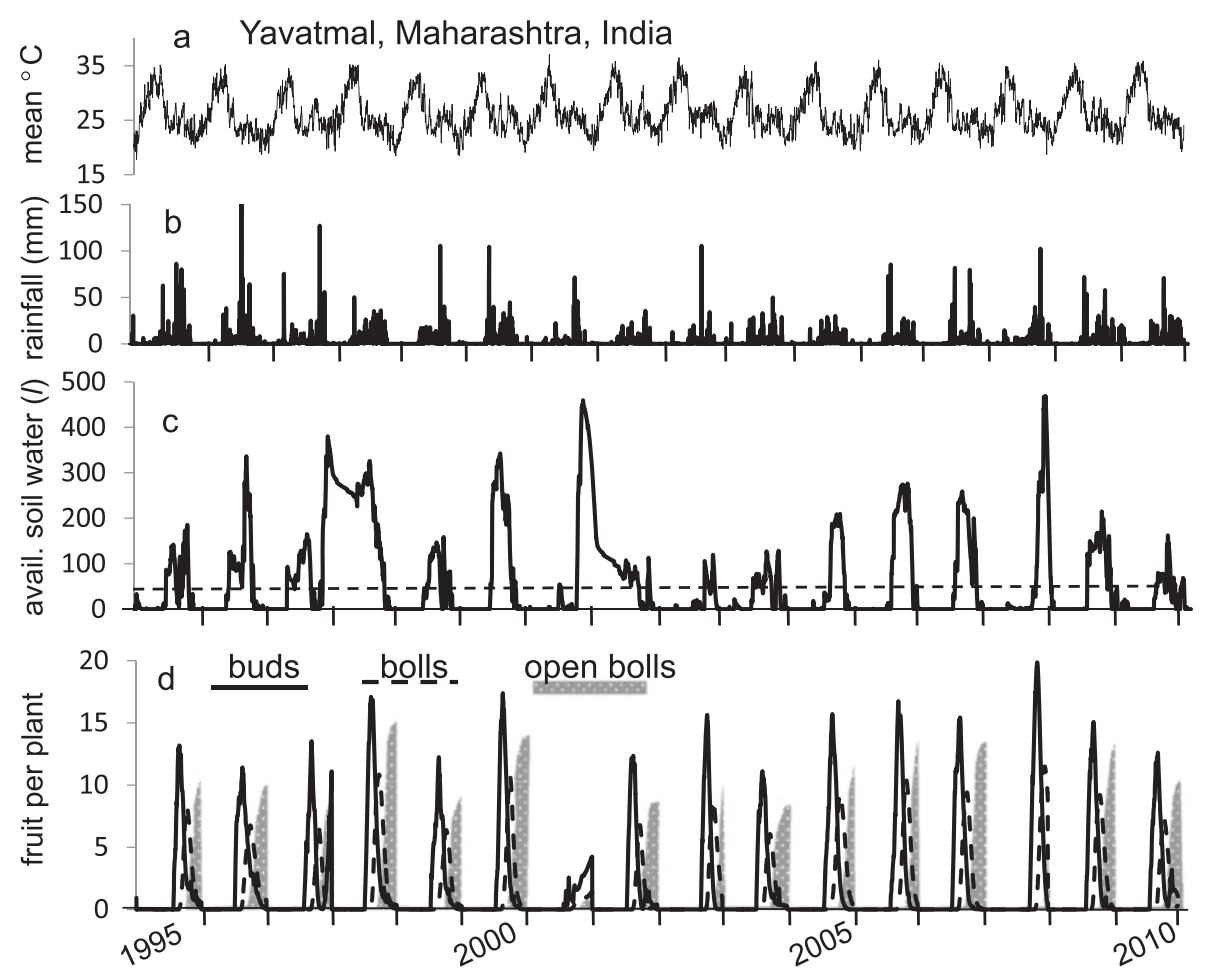

Fig. 3 Simulation of rainfed non-Bt cotton at Yavatmal, $\mathrm{MH}\left(78^{\circ} 9^{\prime} \mathrm{E}, 20^{\circ} 10^{\prime} \mathrm{N}\right)$ for the period 1995-2010: a mean daily temperature and $\mathbf{b}$ daily rainfall, c available soil water in the root zone, and $\mathbf{d}$ simulated fruiting dynamics per plant at a planting density of six plants $\mathrm{m}^{-2}$ (see location symbol black circle in Fig. 1). The horizontal dashed line in Fig. $3 \mathrm{c}$ is the wilting point. Results for 16 of the 31 years are illustrated
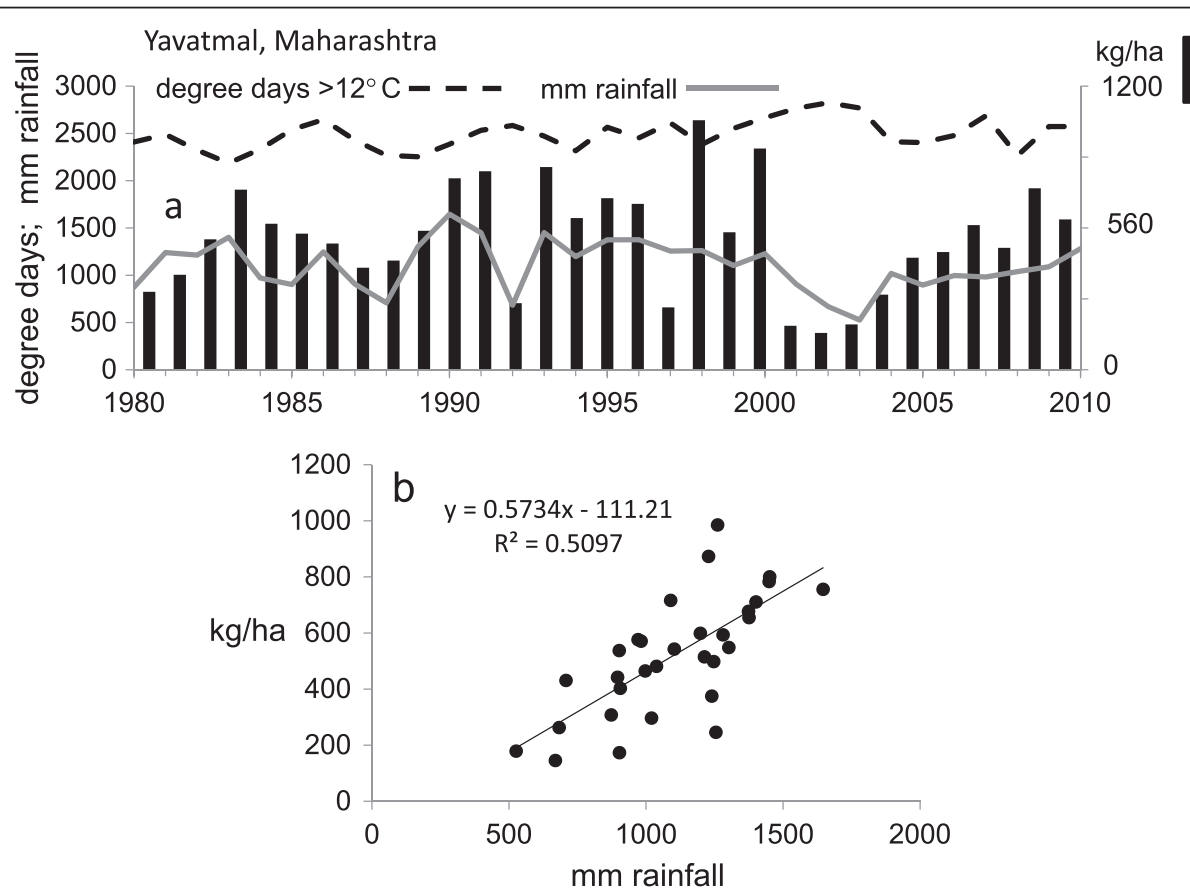

Fig. 4 Simulated annual yields of rainfed non-Bt cotton at Yavatmal, MH, during 1980-2010: a lint cotton ( $\mathrm{kg} / \mathrm{ha}$, bars), degree days $\left(>12^{\circ} \mathrm{C}\right.$, dashed line), and $\mathrm{mm}$ rainfall (gray solid line) during the season, and $\mathbf{b}$ linear regression of yield on $\mathrm{mm}$ rainfall (see text) 
averaged $521 \mathrm{~kg}$ lint cotton $\mathrm{ha}^{-1}(\mathrm{SD}= \pm 212.1)$ (Fig. 4b; Eq. $1)$.

$$
\begin{aligned}
& y=-111.2+0.573 \text { rainfall } \\
& d f=29, r^{2}=0.509, \quad t=5.49
\end{aligned}
$$

\section{Pest interactions between irrigated and rainfed cotton}

Some irrigated cotton is grown in predominantly rainfed areas such as Yavatmal (Fig. 1), and PBW populations building up in irrigated fields can then invade rainfed cotton (Fig. 5) and multiply further. This may amplify feedback between the two systems, encouraging pesticide use in both that induces secondary pests such as bollworm regionally. Although PBW adults are not strong fliers, adult moths are known to disperse long distances in the southwest USA on North American monsoon winds [36], and similar monsoon dispersal likely occurs in India.

\section{Rainfed cotton production in India}

In this section, we first assess rainfed cotton production across the agro-ecological zones of India and then focus on the states of AP, GJ, KA, and $\mathrm{MH}$.

Prospective average yields of rainfed cotton across India during 1980-2010 and coefficients of variation $(\mathrm{CV})$ as a percent are shown in Fig. 6a, b, respectively, with average annual rainfall illustrated in Fig. 6c. Multiple regression of average rainfed yields (data from Fig. 6a) on total degree days during the growing season $\left(\mathrm{dd}>12{ }^{\circ} \mathrm{C}, t=7.34\right)$, rainfall $(t=-13.83)$, and the interaction term dd $\times$ rainfall $(t=35.12)$ is summarized by Eq. 2 .

$$
\begin{aligned}
& y=78.72+0.0593 \mathrm{dd}-0.1303 \text { rainfall }+0.000153 \mathrm{dd} \\
& \times \text { rainfall } \\
& F=2836, d f=2835, \quad R^{2}=0.75
\end{aligned}
$$

Rainfed yields increase with dd and the interaction $\mathrm{dd} \times$ rainfall, but decrease with rainfall (Eq. 2). In the absence of pests and using average values $(\mathrm{dd}=2361$, rainfall $=1430 \mathrm{~mm})$, marginal analysis $\left(d y / d x_{i}\right)$ suggests that rainfall contributes $0.230 \mathrm{~kg} \mathrm{ha}^{-1} \mathrm{~mm}^{-1}$ of rain to potential yield given the average effects of $\mathrm{dd}$, while dd contributes $0.278 \mathrm{~kg} \mathrm{ha}^{-1} \mathrm{dd}^{-1}$ given the average effects of rainfall.

Average yields for AP, GJ, KA, and $\mathrm{MH}$ and India (not shown) are inversely related to the CV (Figs. 7a-d). As a metric of weather-related risk, we define high-risk areas as having average yields $<500 \mathrm{~kg} \mathrm{ha}^{-1}$ and $\mathrm{CV}>50 \%$. Using this metric, GJ has relatively few high-risk areas, $\mathrm{KA}$ has a large number, and $\mathrm{AP}$ and $\mathrm{MH}$ are intermediate. In $\mathrm{MH}, \sim 90 \%$ of farmers grow some cotton, and about $40 \%$ of the state has CVs $>50 \%$ (see insets Fig. 7d). The relative level of risk for each state (i.e., $\mathrm{GJ}<\mathrm{MH}<\mathrm{AP} \ll \mathrm{KA}$ ) is reflected in the state's production as a percentage of national cotton production. Specifically, during 2002-2011, production in GJ ranged from 24 to $39 \%, 15$ to $26 \%$ in $\mathrm{MH}, 13$ to $19 \%$ in $\mathrm{AP}$, and only 2 to $4 \%$ in KA [37]. This metric of risk could also apply to other rainfed crops.

\section{Discussion}

Here we review some economic studies on the benefits of Bt cotton adoption, the biological and ecological underpinnings of the Indian cotton system, and the question of

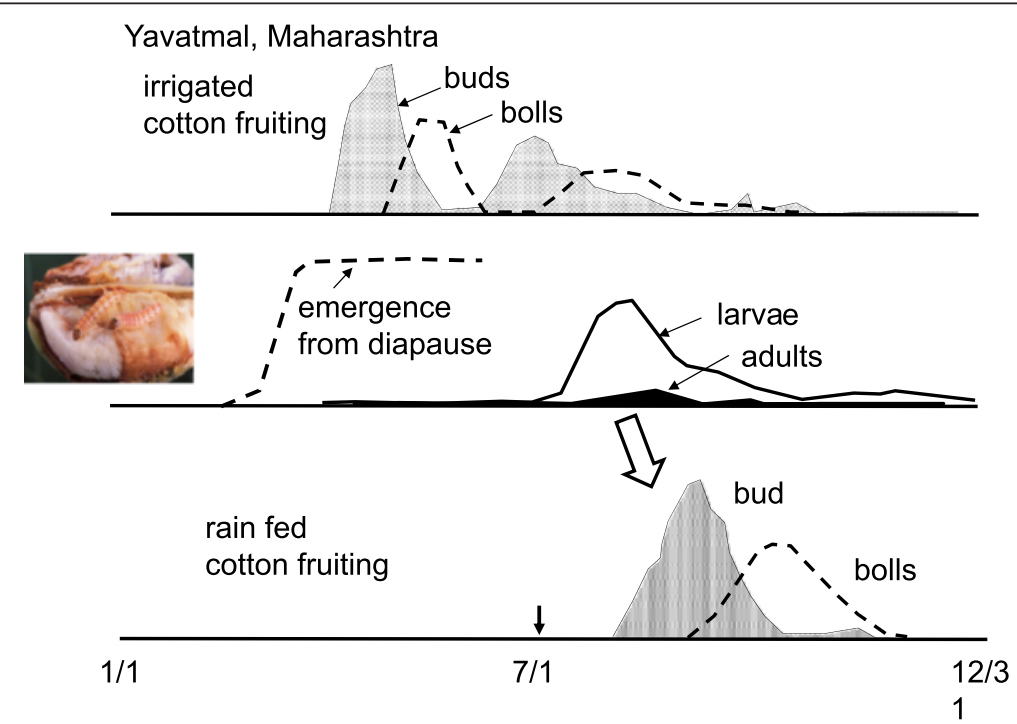

Fig. 5 Simulated phenology of cotton fruiting and PBW in irrigated and rainfed cotton at Yavatmal, MH, during 2005. The movement of adults to rainfed cotton during late summer is indicated by the broad arrow 


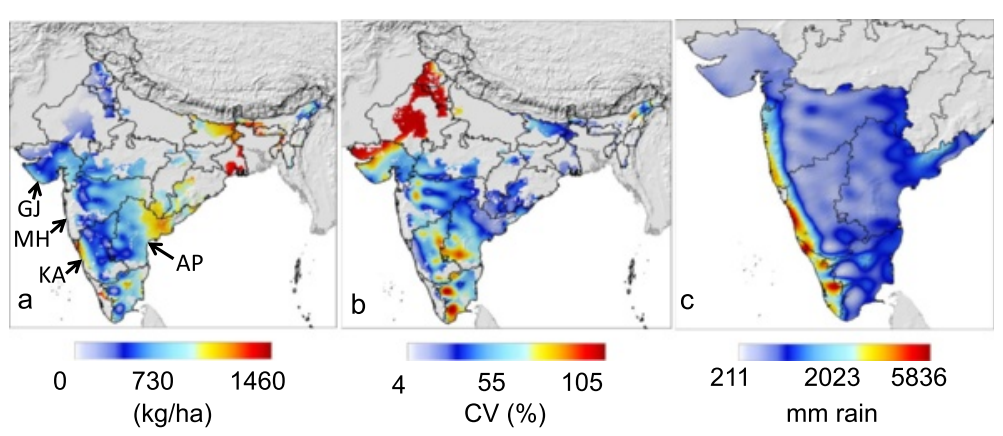

Fig. 6 Simulated rainfed yields for the period 1980-2010 across India: a average yield, b the coefficient of variation (CV) of yield, and c average annual rainfall $(\mathrm{mm})$.

whether the Bt cotton technology was needed, under what conditions might it give economic benefits, is its adoption linked to farmer suicide, who might profit from Bt cotton adoption, and lastly how climate change will impact rainfed cotton production.

\section{Review of the economics of Bt cotton adoption}

Numerous economic studies based on field experiments and survey data have found economic benefits for Bt cotton adoption in India [38], and yet, controversy persists (see the cogent expośe by Stone [39]). Econometric analyses ignore the underpinning ecology of the system and disregard underlying agro-ecological principles of yield formation (see Additional file 1) [40]. In particular, prior economic studies of Indian cotton compared the failed insecticide technology to the Bt technology option, ignoring the question of whether either technology was needed in the first place. Econometric analyses tell little about the root causes of the problem being evaluated or alternatives to the current production system and, most important, provide little insight into what is foremost an ecological problem with economics superimposed $[16,41]$. Specifically, studies in ecologically disturbed environments limited to isolated small plots typical of published results from India, rather than in larger landscape and historical frameworks, are known to bias results against untreated checks (see [34, 42-44]), inputs such as fertilizer and water are often not experimentally controlled [45], in south-central India, ground water is being used unregulated and unpriced [26], industry data have

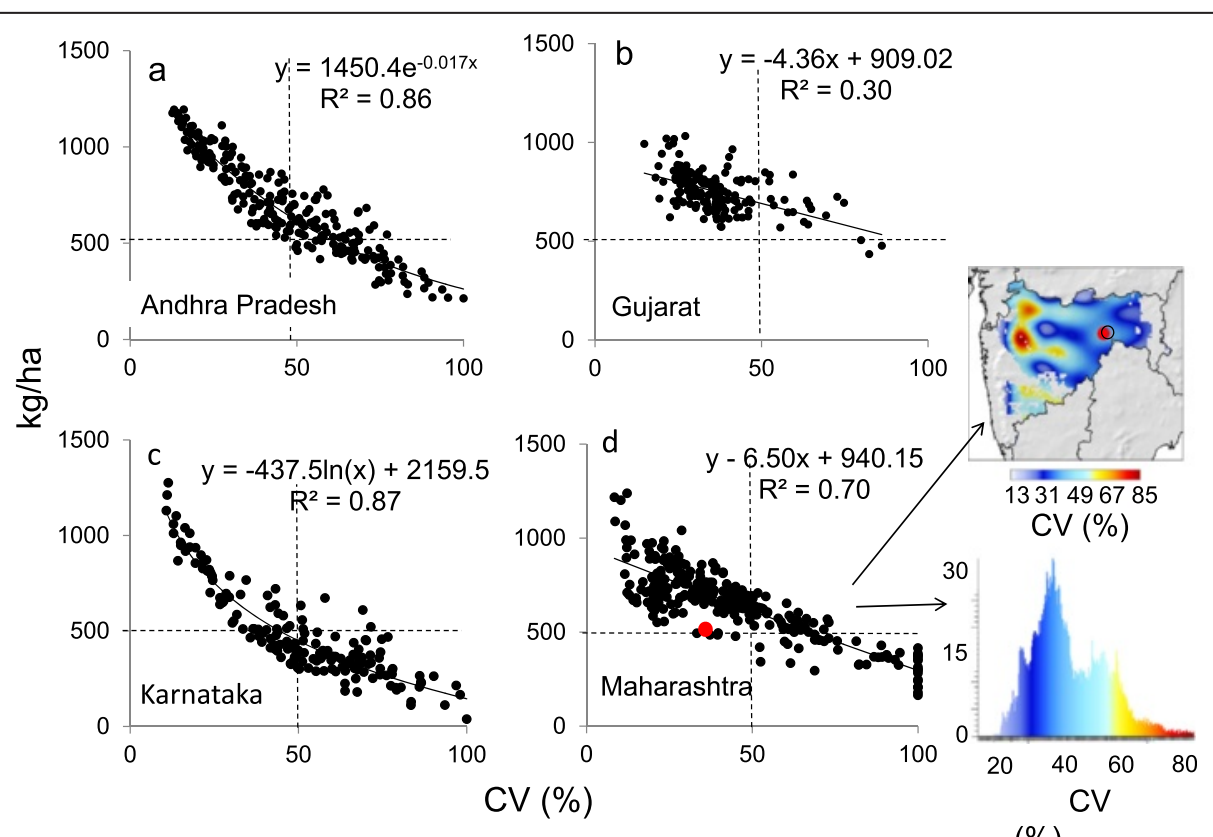

(\%)

Fig. 7 Regressions of average rainfed yield (kg/ha) on the coefficient of variation (\%) for a Andhra Pradesh, b Gujarat, c Karnataka, and d Maharashtra. The right inset map for Maharashtra shows the geographic distribution of CV while the histogram shows the frequency of the different CV categories. Yavatmal, $\mathrm{MH}$, is indicated in Fig. $7 \mathrm{~d}$ and the upper inset by symbols red circle and black circle, respectively 
been used to predict unrealistic estimates of potential yield [20], and generally, important agronomic aspects of the systems (e.g., irrigated vs. rainfed, planting density, varieties, pest dynamics, etc.) and the crucial effects of weather are ignored. For example, higher yields were found for Bt compared to conventional cotton [46], but in critique of this and related studies, a high degree of variation in productivity and profits with other social and economic explanations was found for yield differences including a "placement bias" of irrigation and "good growing conditions" [22]. Insecticides continue to be used in Bt cotton in India, and as in China productivity effects of Bt cotton and pesticide use likely depend on the action of natural control agents with the profitability of damage control measures increasing with the severity of ecosystem disruption due to insecticides [47].

\section{Biological and ecological underpinnings}

Economic analyses commonly assume that cotton pests must be controlled to prevent economic losses. However, in an 11-year study of rainfed cotton at Nagpur, MH, India (near Yavatmal) using the non-Bt G. hirsutum hybrid $\mathrm{NHH}-44$ under organic and conventional practices, Blaise [5] found higher yields and lower pest damage in organic cotton. Fundamental to understanding this result is that annual emergence of the key pest PBW in spring is poorly timed to attack rainfed cotton and absent high inoculum from irrigated cotton (Fig. 5), large PBW populations fail to develop in non-Bt rainfed cotton. This biology reduces and usually obviates the need for Bt cotton and disruptive insecticides (see Figs. 3 and 5), thus avoiding ecological disruption and outbreaks of bollworm and other secondary pests (sensu [11]) that may be far more damaging and difficult to control than PBW $[8,9]$. Prior to 1970 , bollworm was not an important pest in Indian cotton [48].

That insecticide can induce pest outbreaks in Indian cotton has abundant parallels worldwide [11, 12, 34, 47, 49-51]. A well-documented example is irrigated industrial cotton in the Central Valley of California during the 1960s and 1970s. While PBW is limited there by winter temperatures [52], insecticide was used to control a presumed pest, the plant bug Lygus hesperus Knight. The insecticide induced severe outbreaks of bollworm, defoliators, and the resurgence of Lygus [34, 51, 53-55] (see Additional file 1), and the studies over several years showed that compared to the insecticide treatments, higher yields of the same quality accrued in the very large untreated check areas [34, 51]. Central Valley farmers had been spending money on insecticide to lose money on lower yields causing economist U. Regev [56] to call this the first documented case of market failure in pest control [6]. Bt cotton has not made inroads in the Central Valley of California though herbicide tolerant cotton is grown [52].
More germane to India is irrigated cotton in the desert valleys of southern California and Arizona where the invasive PBW caused heavy losses during the mid-1970s to the mid-1980s, and insecticide use for its control caused severe outbreaks of bollworms, budworms, defoliators, and whiteflies [11, 27, 57]. The problem was initially solved using high-density short-season cotton that produced high yields, but the technology requires early crop termination and plowing of the stubble to destroy residual dormant PBW populations (see Additional file 1) [32]. Short-season cotton was replaced by fertile Bt cotton despite no increases in yield because implementation requirements were less stringent, it gives excellent control of PBW [58], and in an industrial setting, the costs of the Bt technology are an acceptable cost-effective alternative to short-season cotton (see Additional file 1). Bt cotton is "softer" on natural enemies than insecticides $[59,60]$ enabling reductions in insecticide use [61] that allows secondary pests (e.g., bollworms, budworms, whiteflies) to recede to prior low pest status [33]. Though not significantly different, mean natural enemy densities in Bt cotton are consistently lower than those in unsprayed non-Bt cotton [62], and the efficacy of some natural enemies is reduced when feeding on Bt-intoxicated prey [63, 64]. For pests such as bollworms and defoliators having high reproductive capacities (500-1000 eggs/female/week) or pests with high tolerance to Bt toxins (e.g., plant bugs, whiteflies, and mealybugs), a small reduction in natural enemy density and efficacy may increase pest density and trigger insecticide use and ecological disruption [33]. Plant bugs have increased in Bt cotton in China and the USA, but this has been dismissed as due to reduced pesticide use [58,65-67], despite strong evidence that insecticide use increases plant bug resurgence [33, 55] (see Additional file 1). In India and Pakistan, sucking insect pests had been of minor concern in cotton but are now increasing in Bt cotton and contribute to yield losses and increased insecticide use $[68,69]$.

In sharp contrast to industrial cotton farms globally, most Indian cotton farms in south-central India are $<1$ ha and are rainfed. Furthermore, F1 Bt hybrids are sold as a value-capture mechanism to discourage seed saving by millions of small farmers who cannot be controlled by threats of lawsuits as occurs in industrial agriculture in more developed areas. Single toxin hybrids may produce $25 \%$ non-Bt seeds and $6.25 \%$ in two toxin hybrids with the seasonal expression of Cry $2 \mathrm{Ab}$ having a wide range with the levels being tenfold higher than for Cry1Ac [7]. Quality control of Bt seed in India is lax [2]; resistance to Bt occurs in PBW [70-72] and in bollworm $[2,73,74]$; and as elsewhere susceptibility to Bt toxins varies greatly among pests (Additional file 1) with insecticide resistance in Bt tolerant pests further complicating pest control $[9,14]$. Insecticide use, while initially 
lower in Bt cotton, has greatly increased against sucking pests $[69,75]$ (Additional file 1: Table S1)

The need for Bt cotton in India must be reevaluated on biological and economic grounds [69] using properly unbiased field experiment unfettered by onerous corporate intellectual property constraints. These constraints were outlined in a 2009 letter to the US Environmental Protection Agency from 26 leading university entomologists from the US corn-belt protesting the restricted access to GMO seeds for experimental purposes: “...No truly independent research can be legally conducted on many critical questions involving these [GMO] crops" [76]. Corporate intellectual property constraints on GMO crops are an impediment worldwide to system-level analysis.

\section{Does $\mathrm{Bt}$ cotton provide economic advantage?}

Average profits per ha in rainfed cotton are computed as revenues from the sale of seed cotton minus average costs of seed, insecticide, and other production costs. On the revenue side, during 2002 to 2013 cotton prices (e.g., Bengal Desi) ranged from Rs 1875 to $4583 / 100 \mathrm{~kg}$ of seed cotton (i.e., $\sim \$ 0.31-\$ 0.75 / \mathrm{kg}$ assuming Rs 61 per $\$$ ) [37]. A midrange value of $\$ 0.51 / \mathrm{kg}$ is used in our calculations. Prior to the advent of hybrid varieties, seed costs were nil to low (Rs $8-9 / \mathrm{kg}$ ), but as fertile local varieties became unavailable, farmers increasingly bought F1 hybrid seed that for Bt varieties cost $\sim$ Rs 2111 per $\mathrm{kg}$. Two $\mathrm{kg}$ of seed are required at traditional planting densities of two plants $/ \mathrm{m}^{2}\left(\sim \$ 69 \mathrm{ha}^{-1}\right)$, but optimal planting densities may be threefold or much higher, depending on the variety (see Additional file 1). At the traditional density, the cost of seed plus insecticide was Rs $5500 \mathrm{ha}^{-1}$ $\left(\sim \$ 90 \mathrm{ha}^{-1}\right)$ for both Bt adopters and non-adopters [46] with an additional Rs 5386 for other production costs [43]. These prices vary in time and region, and hence, they must be viewed as reference values.

Observed average yields for rainfed cotton in the four target states ranged from $300 \mathrm{~kg} \mathrm{ha}^{-1}$ to $1200 \mathrm{~kg} \mathrm{ha}^{-1}$ lint cotton with yields in a few districts of AP and KA exceeding $1200 \mathrm{~kg} \mathrm{ha}^{-1}$ [35]. Note that lint cotton is roughly $30-35 \%$ by weight of seed cotton. In the absence of pest damage, average simulated rainfed yields for AP, GJ, KA, and $\mathrm{MH}$ accord with these values (Fig. 8a) with roughly half of the area producing less than $500-\mathrm{kg}$ lint cotton ha ${ }^{-1}$ (Fig. 8b). (Yields in irrigated cotton would be at or above the upper end of this range.) Total costs of production for the small proportion of rainfed farms with yields of $1320-\mathrm{kg}$ cotton ha ${ }^{-1}$ are $\sim 8 \%$ of the revenues. In contrast, production costs for farms with yields of $500 \mathrm{~kg} \mathrm{ha}^{-1}$ are $\sim 21.1 \%$ of the total revenues resulting in a net income $<\$ 2$ day $^{-1} \mathrm{ha}^{-1}$ farmed. At $250 \mathrm{~kg} \mathrm{ha}^{-1}$, costs consume $\sim 42.2 \%$ of the revenues resulting in a net income of $<\$ 1 \mathrm{day}^{-1} \mathrm{ha}^{-1}$ (see Fig. 8a). Costs as a proportion of revenues decrease exponentially with increasing yields (9200yield ${ }^{-0.965}$ ) becoming $100 \%$ at $\sim 78.5-\mathrm{kg}$ lint cotton $\mathrm{ha}^{-1}$.

In rainfed areas, low yields and high variability are substantial sources of risk [22, 77] (see Figs. 4 and 7), with the high costs of Bt cotton seed and continued use of insecticide being added destabilizing factors. Debt has long been a dominating factor in Indian agriculture, and recently, official sources of credit have greatly decreased,

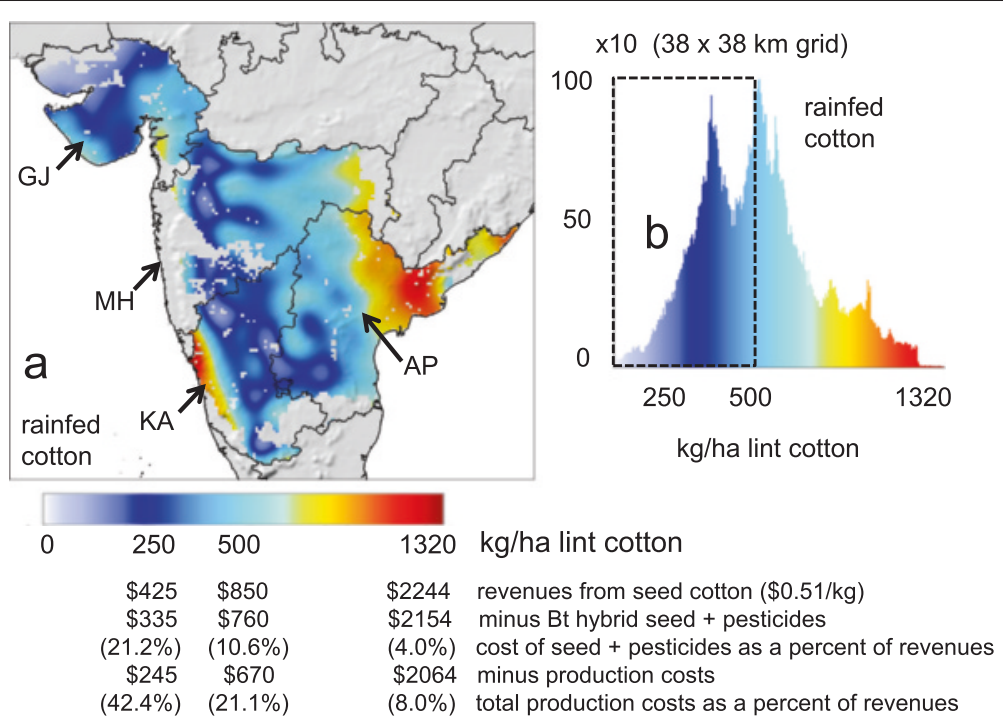

Fig. 8 Cotton yields, revenues, and costs in rainfed cotton areas of AP, GJ, KA, and MH: a geographic distribution of average lint cotton yields during 1980-2010, and revenues per hectare corrected for seed and insecticide costs [46] and other costs of productions [43]; and $\mathbf{b}$ a histogram of lint cotton yields (kg/ha). Costs of production as a percentage of total revenues are in parentheses in legend for Fig. 8 a 
and usury costs (5-10\% per month) to money lenders and others sources have become an added burden for poor farmers seeking to fund new technology adoption [23].

\section{Did Bt cotton increase yield?}

Bt cotton is not a yield enhancing technology, rather, it is designed to protect the yield potential of the variety that carries the trait from damage from some but not all lepidopteran pests (see above and Additional file 1). Average yields for India during 1975-2007 are illustrated in Fig. 9a with the apparent increase in the national average after 2004 attributed to Bt cotton adoption [19], despite the fact that the adoption rate was only $8 \%$ in 2005 and $42 \%$ in 2006 [78], that government subsidies for fertilizer (primarily urea) during 2003-2011 increased approximately fivefold (i.e., 110 to 600 billion Rs or about US\$2 to 10 billion) [79], that data from irrigated and rainfed cotton were conflated in the average, and that agronomic practices and varieties were improving (see below). Variety improvements, fertilizer, rainfall amount and time, reduced pesticide use, and changes in planting densities can have large effects independent of the Bt technology. The large effects of genotype $\times$ spacing in rainfed cotton were demonstrated using fertile non-Bt G. hirsutum and Desi (G. arboreum) varieties with one variety yielding $1967 \mathrm{~kg} \mathrm{ha}^{-1}$ of lint cotton at 16.6 plants $\mathrm{m}^{-2}$ that was $>60 \%$ higher than that at 5.5 plants $\mathrm{m}^{-2}$ [80].

The post-2004 yield data appear to be on the same increasing trend (dashed line in Fig. 9a) as before the introduction of Bt cotton when improved hybrid varieties began entering the market. We posit that the stippled area below the dashed line is a rough estimate of yield loss commonly observed in ecologically disrupted cotton systems with increasing insecticide resistance (e.g., California).
Cotton in $\mathrm{MH}$ is predominantly rainfed, and yields before 2002 were increasing, but the level was well below the national average (Fig. 9b), while yield gains in AP were flat (not shown). Yield stagnation occurred nationally during the period 2005 to 2013 at about $~ 510-\mathrm{kg}$ lint cotton ha ${ }^{-1}$ $[2,75]$ (see Additional file 1: Table S1). Yields in GJ and AP peaked before 2007 and then declined sharply, while yields in $\mathrm{MH}$ and $\mathrm{KA}$ continued to increase (Fig. 9c).

\section{Are farmer suicides linked to Bt cotton adoption?}

The reason for individual suicides is varied, and in India, it must be viewed against the webbed nuance of social (e.g., caste, religious and cultural), ecological, and economic factors of Indian agricultural society (see [23]).

A tenfold greater age-standardized suicide death rate occurs in the southern states of India compared to northern states [81]. Economists examined the national suicide data for 1997-2007 and concluded that there was no link of farmer suicides to Bt cotton adoption [19]. Indeed, plots of annual suicides in GJ and KA show no trend with time (Fig. 10a) or on the national total of suicides. Suicides in GJ were about 500 per year $(<3 \%$ of the national total), while cotton production was $24-39 \%$ of the national total [37], and average yields were mostly $>500-\mathrm{kg}$ lint cotton $\mathrm{ha}^{-1}$ with $\mathrm{CV}<50$ \% (Fig. 7b). Farmer suicide rates in KA were high at about 2000 annually, but cotton production was only $2-4 \%$ of the national total with predicted yields $<500 \mathrm{~kg}$ and $\mathrm{CV}>50 \%$ being very common (Fig. 7c). In KA, these are indicators of risk not only in cotton but also in other parts of the agriculture sector due to low and highly variable rainfall. In $\mathrm{AP}$ and $\mathrm{MH}$, suicides are strongly increasing with time (Fig. 10b) and on the national total (Fig. 10c) with the increase beginning before the introduction of $\mathrm{Bt}$ cotton in

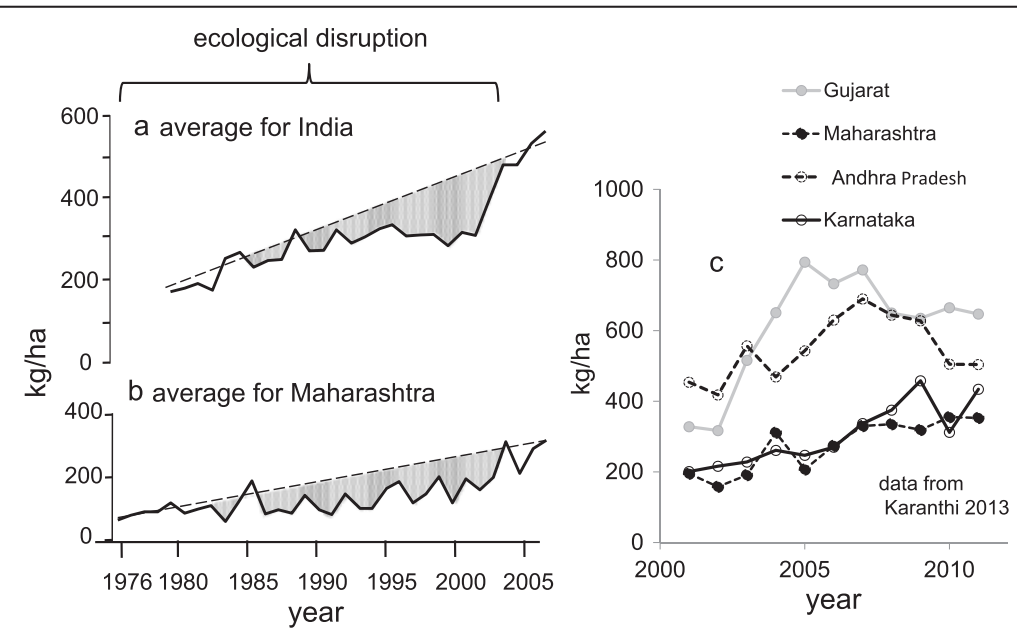

Fig. 9 Average lint cotton yield across areas with rainfed cotton: a India and $\mathbf{b}$ Maharashtra (data from [19]), and $\mathbf{c}$ average lint yields in four states of south-central India during 2001-2010 (i.e., AP, GJ, KA, and MH; data from [2]). The stippled area is posited to be due to pesticide-induced disruption (see bracket above Fig. 9a, e.g., [34]) 


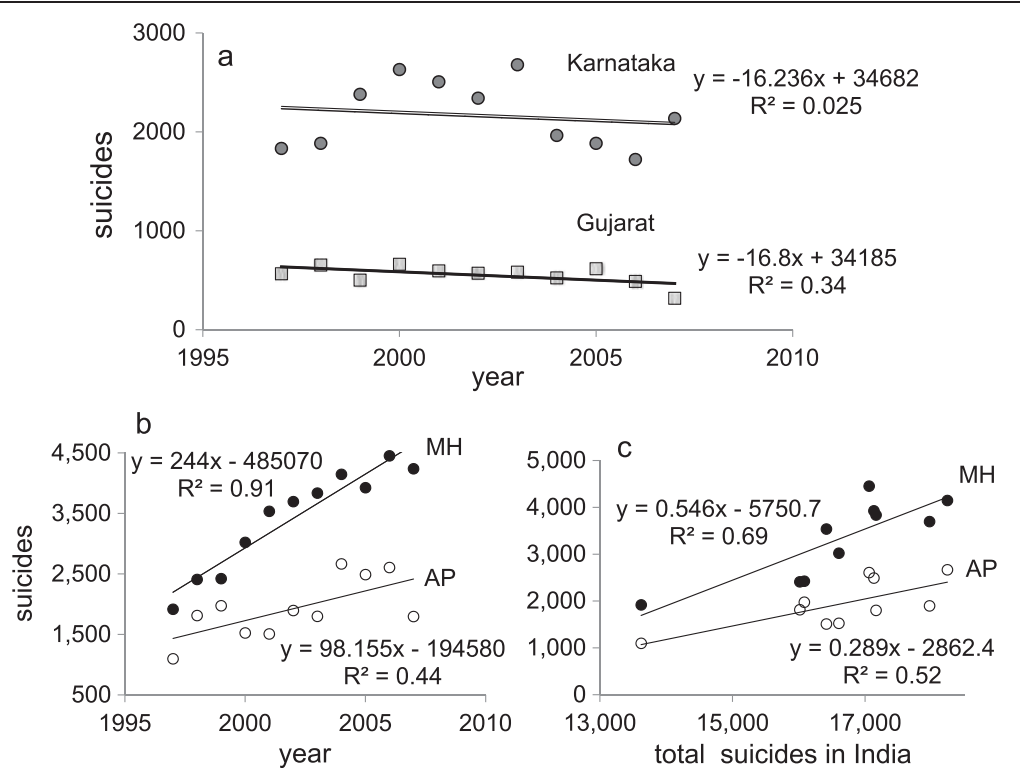

Fig. 10 Farmer suicides in India during the period 1997 to 2007 (data from [19]): a in Gujarat and Karnataka, b Maharashtra, and Andhra Pradesh, and $\mathbf{c}$ plots of suicides in Andhra Pradesh and Maharashtra on the total for India

2002. The contributions to national cotton production in $\mathrm{MH}(15-26 \%)$ and AP (13-19\%) are similar, and high-risk areas (i.e., yield $<500 \mathrm{~kg}, \mathrm{CV}>50 \%$ ) are common in both states (see Fig. 7a, d). In MH, $90 \%$ of the farmers grow some rainfed cotton, and the state is a hot spot for suicides [23]. Regressing combined annual suicides in AP, GJ, KA, and MH $(y)$ on the national total $(x)$ yields an increasing relationship $(y=0.90 x-$ 7461.3, $R^{2}=0.823$ ).

Revisiting the raw annual suicide data for AP, GJ, KA, and $\mathrm{MH}$ during the period 2001-2010 [82], 86,607 of 549,414 suicides were by farmers, and $87 \%$ were males with the numbers peaking in the 30-44 age class (Additional file 1). Details concerning cotton cultivation, farm size, and other important factors were not reported for each suicide, and hence, as in [19], we were forced to aggregate the data by state. Total suicides per year per state were regressed singly on states averages of proportion of area seeded to rainfed cotton $(t=15.64)$, average farm size $(t=-8.90)$, cotton growing area $\left(\times 10^{3} \mathrm{ha}\right.$, $t=1.90)$, area of Bt cotton $\left(\times 10^{3}\right.$ ha, $\left.t=1.69\right)$, proportion of area with Bt cotton $(t=1.13)$, and simulated average yield/ha $(t=-0.47)$ that includes the effects of weather (see "Methods"; Additional file 1).

Excluding the proportion of area seeded to rainfed cotton, linear multiple regression without transformation of the data (Eq. 3) shows suicides decrease with increasing farm size and yield but increase with the area under Bt cotton cultivation (i.e., $\mathrm{Bt}_{\text {area }}$ is ha $\times 10^{3}$ ). Farm size and yield are measures of poverty and risk, while the increase in Bt area is a surrogate for high costs of Bt technology adoption and continued use of insecticide.

$$
\begin{aligned}
\text { suicides }= & 14,056-6933.0 \text { farm }_{\text {size }}-2.067 \text { yield } \\
& +0.3029 \mathrm{Bt}_{\text {area }} \\
R^{2}= & 0.76, d f=36, \quad F=38.66
\end{aligned}
$$

The means of the independent variables and $t$ values for the regression coefficients are farm size $(1.568 \mathrm{ha}$, $t=-9.93)$, yield(603.8 $\mathrm{kg} / \mathrm{ha}, t=-3.25), B t_{\text {area }}(743.4$ $h a, t=2.84)$.

We note that the high variability associated with low yield is a further dimension of risk (Fig. 7).

\section{Factors affecting suicide rates}

Economic distress can be a proximal cause of suicide, and at least seven factors appear to have influenced this in rainfed areas where cotton is a cash crop: (1) weather-related intrinsic low average yields and high variability [23] (Figs. 7 and 8); (2) increasing insecticide use before 2002 that increased costs and yield losses due to ecological disruption by induced pests (see text; Fig. 9); (3) high costs of Bt cotton seed, fertilizers, insecticide, and ecological disruption and crop loss after the introduction of Bt cotton (e.g., Fig. 8); (4) crop losses due to ill adapted and possibly ineffective Bt varieties $[7,19]$; (5) increased usury costs to fund the new technologies; (6) suboptimal planting densities [80]; and (7) the uncertain effects of weather (e.g., drought or excessive rain as occurred in 2013) on pest and yield. Factors 2-5 are industry driven, and increase bankruptcy rates as farmers assume the gamble in the monsoon [23]. As in China, risk-averse subsistence Indian farmers likely use greater quantities of pesticides that do not increase yield potential but may increase ecological disruption and risk 
of crop failure [83]. Sound information to enable cotton farmers to make informed decisions about plant densities, varieties, pest control practices, and whether to plant Bt cotton is largely unavailable [84]. This information gap was exploited by the insecticide industry before the introduction of Bt cotton and by the seed and chemical industry since. Technology promoters appear more interested in instrumentalizing the technologies for profit than in explaining the underlying causes of yield variation or to find satisfactory cheaper alternative solutions (e.g., high-density short-season cotton). Promoters willingly offer apparent solution with little regard for consequences. Instrumentalization of insecticides and $\mathrm{Bt}$ technology and their adoption by small stakeholders in India has hindered progress on ecologically based cotton production [85] and has contributed to human suffering. Economic analyses decoupled from the ecological and historical roots of the production problem confound the situation, and making the claim that the market determines the usefulness of Bt cotton and insecticide in India (and elsewhere) shameful (sensu [56]).

\section{Does $\mathrm{Bt}$ cotton have a role in Indian cotton?}

Absent resistance to Bt toxin [71], quality Bt cotton provides excellent control of PBW [86] and good control of bollworm and would appear to have a role in highyielding irrigated long-season cotton in India where PBW is a chronic problem and where the marginal cost of the technology is low. Proponents of Bt cotton claim that it reduces the input of disruptive insecticides and greatly reduces ecological disruption, but ultimately, this has not proven to be the case as year 2013 insecticide use is at year 2000 levels [69] (Additional file 1: Table S1). Most cotton in India is rainfed, and Bt cotton provides only prophylactic protection against late season spillover of pink bollworm from irrigated fields (see Figs. 1, 5) and against outbreaks of bollworm and Bt susceptible pests caused by area-wide insecticide disruption. Bt cotton is only a partial solution because it is ineffective against many cotton pests and may help induce outbreaks of others (e.g., sucking pests such as aphids, mealy bugs, jassids, and plant bugs) and result in increased insecticide use [72]. More importantly, the cost of Bt cotton as a proportion of the total revenues to small farmers in rainfed areas can be very high (Fig. 8), and effective implementation of the technology requires among other things such as quality control of varieties, optimal planting density, resistance management to preserve susceptibility to Bt [87], and avoidance of insecticide use. These factors are major constraints in the predominant rainfed small farm cotton culture of south-central India.

The propensity of Indian cotton farmers to extend the season to harvest late-season bolls is counter- productive as $\mathrm{PBW}$ and bollworm infestations can then develop and increase intra-season carryover of pests. Short-season cottons can be high yielding and are designed to set and mature bolls quickly, lessening the need for insecticide for late-season pink bollworm (and bollworm) infestations. Customizing the technology developed with high-density short-season non-Bt cotton for irrigated cotton in southern California [32] (Additional file 1) appears to be a viable solution for irrigated cotton in India [80]. Variations of this technology would also be applicable to rainfed cotton in central and south India where rainfall is low and variable and in areas of south India where a portion of the PBW population does not enter diapause [88]. Furthermore, physiologically based demographic models (see "Methods") as used here could provide a rapid way of evaluating short-season cotton varieties and control strategies for cotton pests in the different regions of India and elsewhere (e.g., [89]).

\section{Climate change effects on rainfed cotton}

Climate change will affect cropping systems globally, and in India, the generalized physiologically based plant simulator INFOCROP was used to simulate the effects of climate change increases in $\left[\mathrm{CO}_{2}\right]$ and temperature on cotton [90]. Global climate model (GCM) temperature scenarios A2, B2, and A1B that respectively project 3.95, 3.20 , and $1.85{ }^{\circ} \mathrm{C}$ increases in mean temperatures with marginal increases in rainfall were used in the study. They found that productivity in northern India may decline marginally while in rainfed cotton in central and southern India productivity may either remain the same or increase. Our results for rainfed cotton in central and southern India, assuming a $2{ }^{\circ} \mathrm{C}$ rise in temperature and no change in rainfall agree with their results. Our model predicts yield increases in most areas of less than $8 \%$ (Fig. 11a, b) with yields decreasing in very low rainfall areas (Fig. 11c). Cotton tolerates high temperatures, and predicted yield increases are due to increases in temperatures during the monsoon season that effectively increase season length (Fig. 3a, b). The results do not change the conclusions about the relative risks of growing rainfed cotton in south and central India, but other high-temperature intolerant crops could be adversely impacted.

\section{Conclusions}

In the light of this more thorough holistic agro-ecological analysis, recommendations by international agricultural economists [20,44] and some Indian government official to implement the Bt technology in cotton (and other crops) as a solution for pest problems become questionable. Worldwide, the use of pesticides to solve pest problems promised short-run economic benefit but instead led farmers onto path dependency $[56,91]$ that increases 

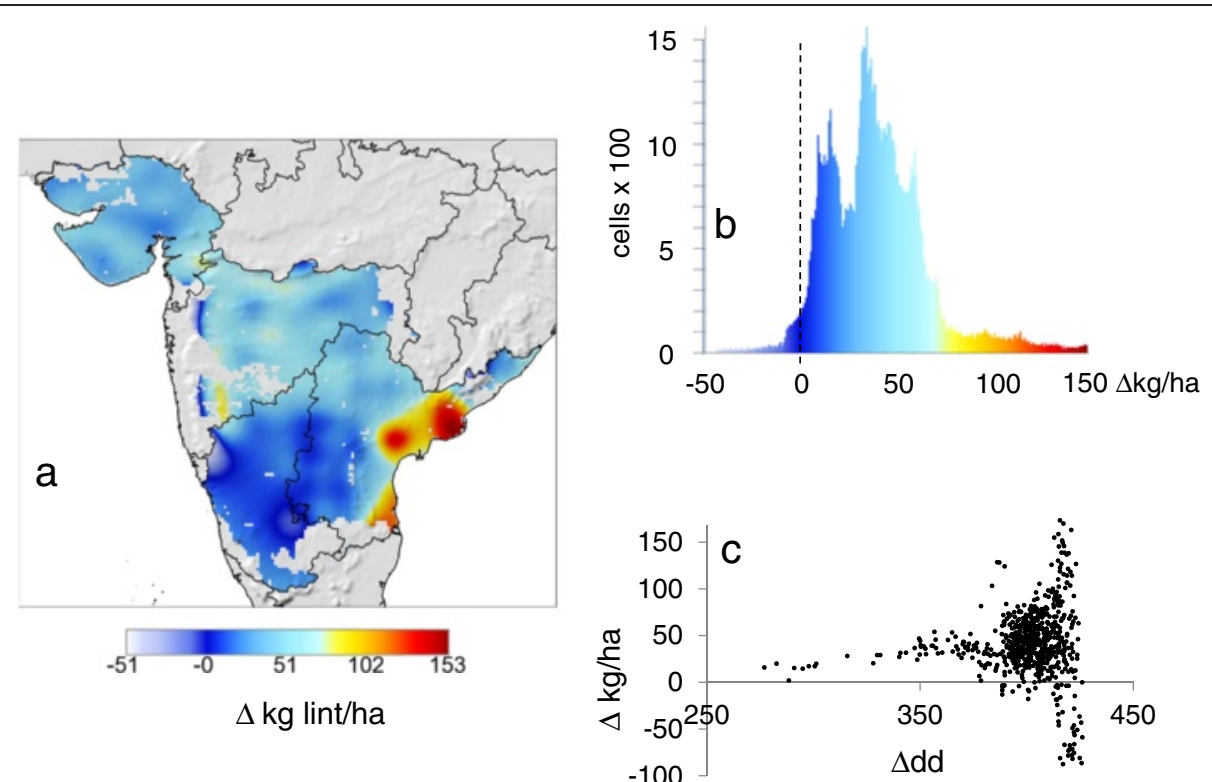

Fig. 11 Changes in cotton yields in $\mathrm{AP}, \mathrm{GJ}, \mathrm{KA}$, and $\mathrm{MH}$ under $+2{ }^{\circ} \mathrm{C}$ climate change and no change in rainfall: a geographic distribution of average changes in lint yield ( $\Delta \mathrm{kg}$ lint/ha), $\mathbf{b}$ a histogram of $\Delta \mathrm{kg}$ lint/ha using the same color rule as in $\mathbf{a}$, and $\mathbf{c}$ plot of $\Delta \mathrm{kg}$ lint/ha on change in degree days $\Delta$ dd

system complexity by inducing pest outbreaks (iatrogenic effects) that may cause crop losses (idiopathic effects) $[34,47,92]$ and increase costs (see Additional file 1). In his 1974 Nobel Prize in Economics lecture titled "The Pretense of Knowledge" concerning larger economic issues, F.A. von Hayek stated “...[economists]...have... little cause for pride: as a profession [we] ... made a mess of things" [93]. In biotechnology, agricultural economists have pushed forward agendas without understanding the ecological bases of the crop production problem and in the process they often wrongly filled the information gaps created by corporate intellectual property constraints on field research on GM crops [76]. The adherence to doctrines that exclusively accept or select observations and disregard fundamental ecological principles for supporting scientific claims imposes serious limitations on their conclusions and has been a hindrance to progress in agricultural research [85]. In India and elsewhere, subsistence farmers often lack a clear understanding of pest control issues that trapped them on a pesticide treadmill (e.g., [11]) and now onto a biotechnology treadmill [33] and that ignores the impending collapse of ground water levels for irrigated cotton [26]. Subsistence farmers, especially in areas with low but high variable yields can ill afford the high costs of industrial farming technologies that contribute to bankruptcy and in some suicide cases.

In review, PBW has been a chronic severe problem in long-season irrigated Indian cotton and can provide inoculum for infestations of rainfed cotton during late summer amplifying feedback and creating an inherent conflict between the two systems. When insecticides became available for control of PBW and other pests, outbreaks of highly damaging bollworms (and other pests) were induced, and F1 Bt hybrid cotton that discouraged seed saving was introduced for control. Prior to the onset of heavy pesticide use, bollworm was not a major pest in Indian cotton [48]. As a percentage of the total revenues, the costs of the $\mathrm{Bt}$ and insecticide technologies decrease with increasing yield making it an acceptable assurance option in high-yield areas, but not in areas with low yields with high variability where the high costs increase the risk of bankruptcy (and suicide). Suicides in rainfed areas of south-central India are inversely related to farm size and yields and directly related to area of $\mathrm{Bt}$ cotton adoption, or more likely the combined high costs of Bt seed and insecticide. Short-season high-density cotton is a viable solution in both irrigated and rainfed cotton reducing the need for the Bt technology. Even where irrigation is available, short-season cotton could be grown rainfed allowing the irrigation water and the period prior to the monsoon to be used for the production of other food crops. This would promote development of diversified and sustainable, including organic agriculture. A recent report shows that despite near complete adoption of Bt cotton in India, insecticide use was higher in 2013 than in 2000 and now targets induced outbreaks of hemipteran insect pests [69]. Last, assuming no change in rainfall, increases in temperature due to climate change during the monsoon season would increase productivity $<8 \%$ in rainfed cotton in central and south 
India. The above results amply illustrate how policy makers need holistic analyses before new technologies are promoted in agricultural development.

\section{Methods}

Physiologically based demographic models (PBDM) of cotton and PBW (see [30, 52, 89]) are used to explain the underlying effects of weather and planting density on yield and PBW dynamics at the local, state, and national levels under irrigated and rainfed conditions prior to the introduction of insecticides and Bt cotton. Such explanatory models reference ecological principles and allow a relaxation of the assumption that only field observations are a valid basis for the study and management of agricultural systems [85].

The cotton PBDM predicts prospectively the daily time-varying age-mass structured growth dynamic of leaves, stems, and roots, and the number-mass age structured dynamics of fruit and yield formation [89] (see Additional file 1). The cotton model has been used in field studies in Arizona, California, Brazil, China, Egypt, and Sudan [31, 34, 47, 89] reproducing the rich biology of growth, development, and yield. The model for India was parameterized using a cotton-growth experiment conducted in 2002 on plant growth (weekly dryweight by subunit and yield) [47]). The model was run using daily weather (see below) under irrigated and rainfed conditions. A water balance model based on [94] was used to estimate the daily effects of water stress on cotton phenology, growth, and yield formation. Daily available soil moisture was computed as the net of current available water above the wilting point plus rainfall minus evapotranspiration as a function of leaf area index and current weather, and runoff above the soil carrying capacity. The moisture holding capacity in the $1 \mathrm{~m}^{2} \times 1.5 \mathrm{~m}$ root zone is assumed $1150 \mathrm{l}$ with a wilting point being $450 \mathrm{l}$.

PBDMs of ten pests of cotton in Arizona-California, including pink bollworm and bollworm (see Additional file 1) were developed and used in analyses of their impact on cotton growth and yield in Arizona and California [27, 29], Brazil [95], Sudan [31], and Egypt [49] (see Additional file 1). Only the pink bollworm model was used in our analysis of Indian cotton. The dynamics of PBW are intimately linked to cotton fruiting phenology, dynamics, and age structure, but unlike bollworm and other cotton pests, PBW attacks the standing crop without affecting plant growth dynamics. A major factor in PBW population dynamics is the evolved adaptation of winter dormancy that enables it to bridge crop cycles. The model captures the phenology of dormancy induction as regulated by decreasing temperature and photoperiod, and spring emergence from diapause as a function of temperature [28] (Fig. 2e, see Additional file 1). The effects of one and two toxin Bt cottons on pest dynamics, crop damage, and development of resistance in PBW and other cotton pests have been modeled [30,33] but were not required in this analysis

\section{Weather data}

The landscape of India, excluding Andaman and Nicobar Islands, was divided into 2855 lattice cells of $38 \times 38 \mathrm{~km}$. Daily weather data (i.e., max-min temperature, solar radiation (cal cm${ }^{-2} \mathrm{~d}^{-1}$ ), $\mathrm{mm}$ rainfall, $\mathrm{RH}$, runs of wind) for each cell during 1979 to 2010 were used to run the PBDMs. The goal was to capture the effects of weather at a regional level, and not to model specific locations or fields, though this is also possible. The weather data are from the Climate Forecast System Reanalysis (CFSR) of the United States National Centers for Environmental Prediction [96]. The CFSR is a global, high-resolution, coupled atmosphere-ocean-land surface-sea ice system that estimates the state of these coupled domains [96]. The data were downloaded using the get_cfsr_latlon function of the R statistical package EcoHydRology [97]. Quality control of the data was made using $1 \%$ random samples for all lattice cells.

\section{Simulation studies and GIS mapping}

Using the weather data to run the model, simulations were made for all of lattice cells of India, but smaller time- and geographic-scale studies were also made. For example, a detailed analysis was made for the lattice cell that includes the village of Telung Takli, Yavatmal, $\mathrm{MH}$ $\left(78^{\circ} 9^{\prime} \mathrm{E}, 20^{\circ} 10^{\prime} \mathrm{N}\right)$ (i.e., the site of the 2012 documentary Bitter Seeds by filmmaker Micha Peled [98]).

Rainfed cotton is planted to germinate at the onset of the monsoon rains of mid to late June, while irrigated cotton is planted in mid-March to April. In the model, the planting date of irrigated cotton is assumed a random variable around day $90 \pm 15$ with harvesting starting in October that can extend as late as February-March the following year. A planting density of 6 plants $\mathrm{m}^{-2}$ is assumed [80,99], with the effects on yield of lower and higher planting densities explored in the supplemental materials. Unless indicated, cotton is non-Bt cotton, and yields are reported as lint cotton that is $\sim 30 \%$ of harvested seed cotton.

The model outputs numerous yearly summary variables (e.g., yield and PBW density), and all were georeferenced and written by year to batch files for mapping and statistical analysis. Means, standard deviations, and $\mathrm{CV}$ as a percent at each location were computed for all variables across years. The cotton-PBW model was assumed equilibrating during the first year, and hence, the data were not used in computing the summary statistics. The summary variables should be viewed as indices of the time-place potential (see text). 
The simulation data were mapped using inverse distance weighting or bi-cubic spline interpolation on a three $\mathrm{km}$ raster grid using the geographic information systems (GIS) software Geographic Resources Analysis Support System (GRASS) [100]. Red on the color bar indicates high favorability, and clear indicates very low favorability.

\section{Analysis of farmer suicides}

Controversy concerning the link of suicides of cotton farmers to increased Bt cotton adoption is widespread in the literature (see text), but a more nuanced approach requires data on other potential contributing variables. Suicide is a crime in India, and the suicide data are from the National Crime Records Bureau of India [82]; distribution of rainfed and irrigated cotton is from the Global Agro-ecological Zones database [25]; average farm size in hectares is for years 2008-2009; estimates of Bt cotton area in India are from the International Service for the Acquisition of Agri-biotech Applications [101], and cotton area is from the M3-Crops Data [24]. The weather-driven estimates of prospective cotton yields are predicted by the model.

\section{Additional file}

\section{Additional file 1: Supplementary materials.}

\section{Abbreviations}

CV: The coefficient of variation; GIS: Geographic information systems (mapping technology); GM: Genetically modified organism (e.g., Bt cotton); PBDM: Physiologically based demographic model; PBW: Pink bollworm.

\section{Competing interests}

The authors declare that they have no competing interests.

\section{Authors' contributions}

APG and LP designed and did the analysis, and all authors contributed to writing the paper. All authors read and approved the final manuscript.

\section{Authors' information}

A.P. Gutierrez is a professor in the Graduate School in the College of Natura Resources at the University of California at Berkeley, CA, and CEO of CASAS NGO. He has more than 40 years of experience in agro-ecosystem analysis and bio-economics with extensive experience in field research in cotton and other crops worldwide.

L. Ponti is Marie Curie Fellow and a research scientist at ENEA with expertise in modeling and GIS.

H. Herren is World Food Prize Laureate and CEO of the Millennium Institute. J. Baumgärtner is retired full professor from the University of Milan with expertise in modeling ecosystems including cotton with interest in philosophical aspects of agricultural systems study and management. P.E. Kenmore has worked over the past 33 years in India, holds an Honorary Doctorate from Wageningen University, the Netherlands, and was formerly head of FAO Plant Protection globally and then head of FAO

(Representative) in India.

\section{Acknowledgements}

We acknowledge the help of Indian researchers who remain anonymous. We are grateful to Dr. M. Neteler (Fondazione Edmund Mach-Centro Ricerca e Innovazione, Trento, Italy, http://gis.fem-environment.eu/), and the international network of codevelopers for maintaining the Geographic
Resources Analysis Support System (GRASS) software and making it available to the scientific community. This research was supported by the University of California at Berkeley, the Center for the Analysis of Sustainable Agricultural Systems (CASAS, www.casasglobal.org), and ENEA, Centro Ricerche Casaccia, Roma, Italy.

\section{Author details}

${ }^{1}$ College of Natural Resources, University of California, 94720-3114 Berkeley, CA, USA. ${ }^{2}$ Center for the Analysis of Sustainable Agricultural Systems (CASAS $\mathrm{NGO}$ ), Kensington, CA, USA. ${ }^{3}$ Agenzia nazionale per le nuove tecnologie, l'energia e lo sviluppo economico sostenibile (ENEA), Centro Ricerche Casaccia, Via Anguillarese 301, 00123 Rome, Italy. ${ }^{4}$ The Millennium Institute, Washington, DC, USA.

Received: 31 October 2014 Accepted: 22 April 2015

Published online: 17 June 2015

References

1. Beckert S. Empire of cotton: a global history. New York, USA: Alfred A. Knopf; 2014

2. Kranthi KR. Bt Cotton: questions and answers. Mumbai, India: Indian Society for Cotton Improvement (ISCI); 2012.

3. Basu AK, Paroda RS. Hybrid cotton in India: a success story. Asia-Pacific Association of Agricultural Research Institutions, FAO Regional Office for Asia \& the Pacific: Bangkok, Thailand; 1995.

4. Prasad CS. Suicide deaths and quality of Indian cotton: perspectives from history and technology and Khadi movement. Econ Polit Weekly. 1999:34:12-21.

5. Blaise D. Cropping and forage systems/crop ecology/organic farming yield, boll distribution and fibre quality of hybrid cotton (Gossypium hirsutum L.) as influenced by organic and modern methods of cultivation. J Agron Crop Sci. 2006;192:248-56.

6. Kranthi S, Kranthi KR, Lavhe NV. Baseline toxicity of Cry1A toxins to the spotted bollworm, Earias vittella F. Crop Protect. 1999;18:551-5.

7. Blaise D, Kranthi KR. Cry1Ac expression in transgenic Bt cotton hybrids is influenced by soil moisture and depth. Curr Sci. 2011;101:783-6.

8. Kranthi KR, Russell DA. Changing trends in cotton pest management. In: Peshin R, Dhawan AK, editors. Integrated pest management: innovation-development. Springer; 2009. p. 499-541.

9. ICAC, International Cotton Advisory Committee. Factors influencing the use of pesticides in cotton in India. Washington DC, USA: Report From the Expert Panel on Social, Environmental and Economic Performance of Cotton Production (SEEP); 2010

10. van den Bosch R, Messenger PS. Biological control. London, UK: Intext Educational Publishers; 1973.

11. van den Bosch R. The pesticide conspiracy. Berkeley: University of California Press; 1978.

12. Zadoks JC, Waibel H. From chemical pesticides to genetically modified crops-history, economics, politics. Netherland J Agric Sci. 2000;48:125-49.

13. DeBach P, Rosen D. Biological control by natural enemies. 2nd ed. Cambridge, UK: Cambridge University Press; 1991.

14. Kranthi KR, Russell D, Wanjari R, Kherde M, Munje S, Lavhe N, et al. In-season changes in resistance to insecticides in Helicoverpa armigera (Lepidoptera: Noctuidae) in India. J Econ Entomol. 2002;95(1):134-42.

15. Herring RJ. Whose numbers count? Probing discrepant evidence on transgenic cotton in the Warangal district of India. J Mult Res Approaches. 2008;2:145-59.

16. Plewis I. Indian farmer suicides: is GM cotton to blame? Significance. 2014;11(1):14-8.

17. Shiva V, Barker D, Lockhart C. The GMO emperor has no clothes. Navdanya International: Florence, Italy and New Delhi, India; 2011.

18. Gruère GP, Mehta-Bhatt $P$, Sengupta D. Bt cotton and farmer suicides in India: reviewing the evidence. IFPRI Discussion Paper 00808. 2008:http:// www.ifpri.org/publication/bt-cotton-and-farmer-suicides-india. Accessed 25 Feb 2014

19. Gruère G, Sengupta D. Bt cotton and farmer suicides in India: an evidence-based assessment. J Dev Stud. 2011;47(2):316-37.

20. Qaim M, Zilberman D. Yield effects of genetically modified crops in developing countries. Science. 2003;299(5608):900-2. doi:10.1126/science.1080609.

21. Stone GD. Field versus farm in Warangal: Bt cotton, higher yields, and larger questions. World Dev. 2011;39(3):387-98. 
22. Glover D. Is Bt cotton a pro-poor technology? A review and critique of the empirical record. J Agrar Change. 2010;10(4):482-509.

23. Vasavi AR. Shadow space: suicides and the predicament of rural India. Three Essays Collective: New Delhi; 2012.

24. Monfreda C, Ramankutty N, Foley JA. Farming the planet: 2. Geographic distribution of crop areas, yields, physiological types, and net primary production in the year 2000. Global Biogeochem Cycles. 2008;22(1):GB1022 doi:10.9/2007GB002947.

25. FAO, Food and Agriculture Organization of the United Nations, IIASA, International Institute for Applied Systems Analysis. Global Agro-ecological Zones (GAEZ v3.0). FAO Rome, Italy and IIASA, Laxenburg, Austria; 2012.

26. Fishman RM, Siegfried T, Raj P, Modi V, Lall U. Over-extraction from shallow bedrock versus deep alluvial aquifers: reliability versus sustainability considerations for India's groundwater irrigation. Water Resour Res. 2011;47(6):WO0L5. doi:10.1029/2011WR010617.

27. Gutierrez AP, Butler Jr GD, Wang Y, Westphal D. The interaction of pink bollworm (Lepidoptera: Gelichiidae), cotton, and weather: a detailed model. Can Entomol. 1977;109(11):1457-68

28. Gutierrez AP, Butler Jr GD, Ellis CK. Pink bollworm: diapause induction and termination in relation to fluctuating temperatures and decreasing photophases. Environ Entomol. 1981:10(6):936-42.

29. Stone ND, Gutierrez AP. A field oriented simulation of pink bollworm in southwestern desert cotton. Hilgardia. 1986:54:1-24.

30. Gutierrez AP, Ponsard S. Physiologically based demographics of Bt cottonpest interactions: I. Pink bollworm resistance, refuge and risk. Ecol Model. 2006;191:346-59.

31. von Arx R, J B, V D. A model to simulate the population-dynamics of Bemisia tabaci Genn. (Stern., Aleyrodidae) on cotton in the Sudan Gezira. Z Angew Entomol. 1983;96(4):341-63.

32. Chu CC, Henneberry TJ, Weddle RC, Natwick ET, Carson JR, Valenzuela C, et al. Reduction of pink bollworm (Lepidoptera: Gelechiidae) populations in the Imperial Valley, California, following mandatory short-season cotton management systems. J Econ Entomol. 1996;89:175-82

33. Gutierrez AP, Adamczyk JJ, Ponsard S, Ellis CK. Physiologically based demographics of Bt cotton-pest interactions II. Temporal refuges, natural enemy interactions. Ecol Model. 2006;191(3-4):360-82.

34. Gutierrez AP, Falcon LA, Loew W, Leipzig PA, van-den Bosch R. An analysis of cotton production in California: a model for acala cotton and the effects of defoliators on its yields. Environ Entomol. 1975;4(1):125-36.

35. Aggarwal PK, B HK, V VM, Rani S, Bala A, Biswa A et al. Quantification of yield gaps in rain-fed rice, wheat, cotton and mustard in India: global theme on agro ecosystems. Report no. 43. International Crops Research Institute for the Semi-Arid Tropics, Patancheru, Andhra Pradesh, India. 2008. http://oar.icrisat.org/2335/. Accessed 25 March 2015.

36. Stern VM. Long and short range dispersal of the pink bollworm, Pectinophora gossypiella, over Southern California. Environ Entomol. 1979;8(3):524-7.

37. The Cotton Corporation of India Ltd. Area, production and productivity of cotton in India from 1950-51 onwards. 2015. http://cotcorp.gov.in/statistics.aspx. Accessed 27 March 2015.

38. Qaim M. Benefits of genetically modified crops for the poor: household income, nutrition, and health. New Biotechnol. 2010;27(5):552-7.

39. Stone GD. Constructing facts: Bt cotton narratives in India. Econ Polit Weekly. 2012;47(38):62-70.

40. Baumgärtner J, Delucchi V, von Arx R, Rubli D. Whitefly (Bemisia tabaci Genn., Stern., Aleyrodidae) infestation patterns as influenced by cotton, weather and Heliothis: hypothesis testing by using simulation models. Agric Ecosyst Environ. 1986;17:49-59.

41. Regev U, Gutierrez AP, Schreiber SJ, Zilberman D. Biological and economic foundations of renewable resource exploitation. Ecol Econ. 1998;26(3):227-42

42. Qaim M. Bt cotton in India: field trial results and economic projections World Dev. 2003;31(12):2115-27.

43. Bambawale OM, Singh A, Sharma OP, Bhosle BB, Lavekar RC, Dhandapani A, et al. Performance of Bt cotton (MECH-162) under integrated pest management in farmers' participatory field trial in Nanded district. Central India Curr Sci. 2004;86(12):1628-33.

44. Naik G, Qaim MAS, Subramanian A, Zilberman D. Bt cotton controversy: some paradoxes explained. Econ Polit Weekly. 2005:40(15):1514-7.

45. Narayanamoorthy A, Kalamkar SS. Is Bt cotton cultivation economically viable for Indian farmers? An empirical analysis. Econ Polit Weekly. 2006;41(26):2716-24
46. Bennett RM, Ismael Y, Kambhampati U, Morse S. Economic impact of genetically modified cotton in India. AgBioforum. 2004;7(3):96-100.

47. Pemsl DE, Gutierrez AP, Waibel H. The economics of biotechnology under ecosystem disruption. Ecol Econ. 2008;66(1):177-83.

48. Nair MRGK. Insects and mites of crops in India. 2nd ed. Indian Council of Agricultural Research: New Delhi, India; 1981

49. Russell D. Report to the Natural Resources Institute on the use of the Moalr/NRI cotton model for pink bollworm control in Fayoum and Beni-Suef. 1995.

50. Fitt GP. An Australian approach to IPM in cotton: integrating new technologies to minimize insecticide dependence. Crop Protect.

2000;19:793-800

51. Falcon LA, van den Bosch R, Ferris CA, Strombert LK, Etzel LK, Stinner RE, et al. A comparison of season-long cotton pest-control programs in California during 1966. J Econ Entomol. 1968;61:633-42.

52. Gutierrez AP, d'Oultremont T, Ellis CK, Ponti L. Climatic limits of pink bollworm in Arizona and California: effects of climate warming. Acta Oecol. 2006;30:353-64. doi:10.1016/j.actao.2006.06.003.

53. Ehler LE, Eveleens KG, van den Bosch R. An evaluation of some natural enemies of cabbage looper in cotton in California. Environ Entomol. 1974;2:1009-15.

54. Eveleens KG, van den Bosch R, Ehler LE. Secondary outbreak introduction of beet army-worm by experimental insecticide application in cotton in California. Environ Entomol. 1974;2:497-503.

55. Gutierrez AP, Wang Y, Regev U. An optimazation model for Lygus hesperus (Heteroptera: Miridae) damage in cotton: the economic threshold revisited. Can Entomol. 1979;111(1):41-54.

56. Regev U. An economic analysis of man's addiction to pesticides. In: Conway G, editor. Pest and pathogen control: strategy tactics and policy models. New York: John Wiley and Sons; 1984. p. 441-53.

57. Gutierrez AP, Ponti L. Eradication of invasive species: why the biology matters. Environ Entomol. 2013;42(3):395-411. doi:10.1603/EN12018.

58. Naranjo SE, Ellsworth PC. Fourteen years of Bt cotton advances IPM in Arizona. Southwest Entomol. 2010;35(3):437-44.

59. Lövei GL, Andow DA, Arpaia S. Transgenic insecticidal crops and natura enemies: a detailed review of laboratory studies. Environ Entomol. 2009;38(2):293-306.

60. Lu Y, Wu K, Jiang Y, Guo Y, Desneux N. Widespread adoption of Bt cotton and insecticide decrease promotes biocontrol services. Nature. 2012;487(7407):362-5.

61. Kouser S, Qaim M. Valuing financial, health, and environmental benefits of Bt cotton in Pakistan. Agric Econ. 2013;44:323-35.

62. Naranjo SE. Long-term assessment of the effects of transgenic Bt cotton on the abundance of non-target arthropods natural enemies. Environ Entomol. 2005;34(5):1193-210.

63. Ponsard S, Gutierrez AP, Mills NJ. Effect of Bt-toxin (Cry1Ac) in transgenic cotton on the adult longevity of four heteropteran predators. Environ Entomol. 2002;31(6):1197-205.

64. Hilbeck A, McMillan J, Meier M, Humbel A, Schläpfer-Miller J, Trtikova M. A controversy re-visited: is the coccinellid Adalia bipunctata adversely affected by Bt toxins? Environ Sci Eu. 2012;24(1):1-12.

65. Lu Y, Wu K, Jiang Y, Xia B, Li P, Feng H, et al. Mirid bug outbreaks in multiple crops correlated with wide-scale adoption of Bt cotton in China. Science. 2010;328(5982):1151.

66. Layton MB. Biology and damage of the tarnished plant bug, Lygus lineolaris in cotton. Southwest Entomol. 2000; Suppl. 23:7-20.

67. Lu YH, Qiu F, Feng HQ, Li HB, Yang ZC, Wyckhuys KAG, et al. Species composition and seasonal abundance of pestiferous plant bugs (Hemiptera: Miridae) on Bt Cotton in China. Crop Protect. 2008;27:465-72.

68. Nagrare VS, Kranthi S, Biradar VK, Zade NN, Sangode V, Kakde G, et al. Widespread infestation of the exotic mealybug species, Phenacoccus solenopsis (Tinsley) (Hemiptera: Pseudococcidae), on cotton in India. Bull Entomol Res. 2009;99:537-41

69. Kranthi KR. Cotton production systems-need for a change in India. Cotton Statistics \& News. 2014;38(16 December 2014):4-7. http://caionline.in/ newsletters/issue 38_161214.pdf. Accessed 27 March 2014.

70. Dhurua S, Gujar GT. Field-evolved resistance to Bt toxin Cry1Ac in the pink bollworm, Pectinophora gossypiella (Saunders) (Lepidoptera: Gelechiidae), from India. Pest Manag Sci. 2011;67(8):898-903.

71. Fabrick JA, Ponnuraj J, Singh A, Tanwar RK, Unnithan GC, Yelich AJ, et al. Alternative splicing and highly variable cadherin transcripts associated with field-evolved resistance of pink bollworm to Bt cotton in India. PLoS One. 2014;9(5), e97900. 
72. Monsanto Company. Pink bollworm resistance to GM cotton in India. 2015. http://www.monsanto.com/newsviews/pages/india-pink-bollworm.aspx. Accessed 27 March 2015.

73. Kranthi KR, Naidu S, Dhawad CS, Tatwawadi A, Mate K, Patil E, et al. Temporal and intra-plant variability of Cry1Ac expression in Bt-cotton and its influence on the survival of the cotton bollworm, Helicoverpa armigera (Hübner) (Noctuidae: Lepidoptera). Curr Sci. 2005;89:291-8.

74. Kranthi S, Dhawad CS, Naidu S, Bharose A, Chaudhary A, Sangode V, et al. Susceptibility of the cotton bollworm, Helicoverpa armigera (Hübner) (Lepidoptera: Noctuidae) to the Bacillus thuringiensis toxin Cry2Ab before and after the introduction of Bollgard-II. Crop Protect. 2009;28:371-5.

75. Xu N, Fok GD, Bai L, Zhou Z. Effectiveness and chemical pest control of Bt-cotton in the Yangtze River Valley. China Crop Protect. 2008;27:1269-76.

76. Pollack A. Crop scientists say biotechnology seed companies are thwarting research. In: The New York Times. 2009. http://www.nytimes.com/2009/02/ 20/business/20crop.html?_r=0\#. Accessed 27 March 2015.

77. Ramasundaram $P$, Vennila $\mathrm{S}$, Ingle RK. Bt cotton performance and constraints in central India. Outlook Agric. 2007;36(3):175-80.

78. Stone GD. Bt cotton, remarkable success, and four ugly facts. In: FieldQuestions.com. 2012. http://fieldquestions.com/2012/02/12/bt-cotton-remarkable-success-andfour-ugly-facts/. Accessed 25 Mar 2015.

79. Srinivasa KYF, Paggi M. A study of Indian government policy on production and processing of cotton and its implications. J Agr Sci Tech B. 2012;2:1016-28.

80. Venugopalan MV, Prakash AH, Kranthi KR, Deshmukh R, Yadav MS, Tandulkar NR. Evaluation of cotton genotypes for high density planting systems on rain fed vertisols of central India. In: Kranthi KR, Venugopalan MV, Balasubramanya RH, Kranthi S, Sing S, Blaise DC, editors. World Cotton Research Conference. Mumbai, India: International Cotton Advisory Committee; 2011. p. 341-6.

81. Patel V, Ramasundarahettige C, Vijayakumar L, Thakur JS, Gajalakshmi V, Gururaj G, et al. Suicide mortality in India: a nationally representative survey. Lancet. 2012;379:2343-51.

82. National Crime Records Bureau. ADSI Info (Accidental Deaths \& Suicides in India). In: Downloads. Ministry of Home Affairs, Government of India. 2013. http://ncrb.nic.in/download.htm. Accessed 19 November 2013.

83. Liu EM, Huang J. Risk preferences and pesticide use by cotton farmers in China. J Dev Econ. 2013;103:202-15.

84. Yang P, lles M, Yan S, Jolliffe F. Farmers' knowledge, perceptions and practices in in transgenic Bt cotton in small producer systems in Northern China. Crop Protect. 2005;24(3):229-39.

85. Rivera-Ferre MG, Ortega-Cerdà M, Baumgärtner J. Rethinking study and management of agricultural systems for policy design. Sustainability. 2013;5:3858-75.

86. Carrière $Y$, Ellers KC, Sisterson M, Antilla L, Whitlow M, Dennehy TJ, et al. Long term regional suppression of pink boll worm by Bt cotton. Proc Natl Acad Sci U S A. 2003;100:1519-23.

87. Tabashnik BE, Brévault T, Carrière Y. Insect resistance to Bt crops: lessons from the first billion acres. Nat Biotechnol. 2013;31(6):510-21.

88. Raina AK, Bell RA. Non-diapausing strain of pink bollworm from southern India. Ann Entomol Soc Am. 1974;67(4):685-6.

89. Gutierrez AP, Pizzamiglio MA, Dos Santos WJ, Tennyson R, Villacorta AM. A general distributed delay time varying life table plant population model: cotton (Gossypium hirsutum L.) growth and development as an example. Ecol Model. 1984;26(3):231-49.

90. Hebbar KB, Venugopalan MV, Prakash AH, Aggarwal PK. Simulating the impacts of climate change on cotton production in India. Clim Chang. 2013;118(3-4):701-13. doi:10.1007/s10584-012-0673-4.

91. Cowan R, Gunby P. Sprayed to death: path dependence, lock-in and pest control strategies. Econ J. 1996;106:521-42.

92. Zhao $\mathrm{H}, \mathrm{Ho} \mathrm{P}$, Azadi $\mathrm{H}$. Benefits of Bt cotton counterbalanced by secondary pests? Perceptions of ecological change in China. Environ Monit Assess. 2011;173(985-994):10661-010.

93. von Hayek F. Nobel Prize Lecture: "The Pretence of Knowledge". In: Nobelprize.org, The Official Web Site of the Nobel Prize. 1974. http://www.nobelprize.org/ nobel_prizes/economic-sciences/laureates/1974/hayek-lecture.html. Accessed 27 March 2015.

94. Ritchie JT. Model for predicting evaporation from a row crop with incomplete cover. Water Resour Res. 1972;8(5):1204-13.

95. Gutierrez AP, Pizzamiglio MA, Santos WJD, Villacorta A, Gallagher KD. Analysis of diapause induction and termination in Pectinophora gossypiella in Brazil. Environ Entomol. 1986;15(3):494-500.
96. Saha S, Moorthi S, Pan H-L, Wu X, Wang J, Nadiga S, et al. The NCEP climate forecast system reanalysis. Bull Am Meteorol Soc. 2010;91(8):1015-57.

97. Fuka DR, Walter MT, Archibald JA, Steenhuis TS, Easton ZM. EcoHydRology: a community modeling foundation for eco-hydrology. R package version 049. 2013:http://CRAN.R-project.org/package=EcoHydRology. Accessed 25 Mar 2015.

98. Peled MX. Bitter seeds. San Francisco, USA: Teddy Bear Films; 2012. http:// teddybearfilms.com/2011/10/01/bitter-seeds-2/. Accessed 27 March 2015

99. Bonde WC, Basu AK, Narayanan SS. Achievements in cotton production technology. In: Basu AK, Narayanan SS, editors. Achievements of AICCIP (1967-92). Coimbatore, India: All India Coordinated Cotton Improvement Project (AICCIP); 1992.

100. GRASS Development Team. Geographic Resources Analysis Support System (GRASS) Software, Version 6.4.2. Open Source Geospatial Foundation. URL http://grass.osgeo.org; 2012.

101. Choudhary B, Gaur K. Bt Cotton in India: A country profile. ISAAA Series of Biotech Crop Profiles. Ithaca, USA: International Service for the Acquisition of Agri-biotech Applications (ISAAA); 2010. http://www.isaaa.org/resources/ publications/biotech_crop_profiles/bt_cotton_in_india-a_country_profile/ download/Bt_Cotton_in_India-A_Country_Profile.pdf.

\section{Submit your manuscript to a SpringerOpen ${ }^{\circ}$ journal and benefit from:}

- Convenient online submission

- Rigorous peer review

- Immediate publication on acceptance

- Open access: articles freely available online

- High visibility within the field

- Retaining the copyright to your article

Submit your next manuscript at $>$ springeropen.com 